IZA DP No. 8809

The Impact of Arab Spring on Hiring and Separation Rates in the Tunisian Labour Market

Ilham Haouas

Almas Heshmati

January 2015 


\title{
The Impact of Arab Spring on Hiring and Separation Rates in the Tunisian Labour Market
}

\author{
Ilham Haouas \\ Abu Dhabi University \\ Almas Heshmati \\ JIBS, Jönköping University, \\ Sogang University and IZA \\ Discussion Paper No. 8809 \\ January 2015 \\ IZA \\ P.O. Box 7240 \\ 53072 Bonn \\ Germany \\ Phone: +49-228-3894-0 \\ Fax: +49-228-3894-180 \\ E-mail: iza@iza.org
}

\begin{abstract}
Any opinions expressed here are those of the author(s) and not those of IZA. Research published in this series may include views on policy, but the institute itself takes no institutional policy positions. The IZA research network is committed to the IZA Guiding Principles of Research Integrity.

The Institute for the Study of Labor (IZA) in Bonn is a local and virtual international research center and a place of communication between science, politics and business. IZA is an independent nonprofit organization supported by Deutsche Post Foundation. The center is associated with the University of Bonn and offers a stimulating research environment through its international network, workshops and conferences, data service, project support, research visits and doctoral program. IZA engages in (i) original and internationally competitive research in all fields of labor economics, (ii) development of policy concepts, and (iii) dissemination of research results and concepts to the interested public.
\end{abstract}

IZA Discussion Papers often represent preliminary work and are circulated to encourage discussion. Citation of such a paper should account for its provisional character. A revised version may be available directly from the author. 


\section{ABSTRACT}

\section{The Impact of Arab Spring on Hiring and Separation Rates in the Tunisian Labour Market}

This paper analyses the hiring and separation rates in Tunisia before and after the Arab Spring of 2011. Several models are specified to study employment decisions based on quarterly administrative firm level data over the period of 2007 to 2012. The data provides information about important firm characteristics such as industry sector, number of hiring and separation, total employment effects and composition of labour force by gender, managerial level and age cohorts. Six models are estimated to investigate hiring, separation, hiring rate, separation rate, mobility, and net-employment. The results indicate presence of continued risk factors in Tunisia's labour market resulting from the global financial crisis in 2008 and the Arab Spring in 2011. Hiring was little changed during this time period, and the results suggest that factors that impact separation decisions remained present in Tunisia's labour market. In addition, the paper looks at various social issues such as youth unemployment and infer on how more efficient policy actions that will further engage the private sector could result in more sustainable positive net-employment and increased labour mobility.

JEL Classification: E24, J23, J63

Keywords: hiring, separation, labour mobility, net-employment, informal sector, Tunisia, Arab Spring, global financial crisis

Corresponding author:

Almas Heshmati

Jönköping International Business School (JIBS)

Jönköping University

Room B5017

P.O. Box 1026

SE-551 11 Jönköping

Sweden

E-mail: almas.heshmati@gmail.com

\footnotetext{
* The authors would like to thank Mrs. Khalid for her excellent assistance during the preparation of this paper.
} 


\section{Introduction}

The Arab Spring spread rapidly throughout Middle East and North Africa (MENA) in 2011, and although it might seem like mere social unrest to general observers, academics and policy makers view this event as a significant response to structural issues in the MENA region labour market. The Arab Spring rocked Tunisia in 2011 and not only it symbolizes the power of ordinary people, but also shed light on the structural economic problems. After all, the Arab Spring has introduced an economic justice problem, namely the failure to sustain inclusive growth, with Tunisia's educated labour force facing increasingly longer waiting periods for public sector jobs (African Development Bank, 2012).

This paper takes a closer look at Tunisia by analysing the impact of the Arab Spring on hiring and separation rates ex post the severe recession in 2011 that pushed Tunisia's unemployment rate near $17 \%$. The country's real GDP growth rate picked up to about $3.6 \%$ in 2012, but the pressure is still on decreasing exports; in addition, high unemployment continues to weigh on the economy. The government responded with a higher wage bill, job creation programs and rising subsidies to manage increasing social demands, but the trade-off of higher government spending swelled its fiscal deficit in 2012. Higher international prices pushed overall inflation rate above $6 \%$, which only added to the problem according to the IMF Mission Chief for Tunisia. Chiraz and Frioui (2014) show the impact of inflation on purchasing power of the Tunisian consumer and investment behaviour.

A previously conducted related research found that before the Arab Spring the financial crisis had a negative impact on the country's economy, causing a GDP decrease from 6.3\% in 2007 to $4.5 \%$ in 2008 (Haouas, Yagoubi, Salvino, 2012). Additionally, labour market characteristics such as gender and age make certain people more vulnerable to recession because of obstacles faced in the labour market (Tzannatos, 2010; Brosius, 2011). Hassine (2015) assesses the levels and determinants of economic inequality in 12 Arab countries using harmonized household survey micro-data. It focuses on the sources of the moderate inequality levels between the countries. Differences in households' endowments such as demographic composition, human capital, and community characteristics appear as the main sources.We relied on the research conducted by Malik and Awadallah (2013) for a more recent perspective on the economics of the Arab Spring. Malik and Awadallah state that although the Arab world is becoming younger and educated, it is still lacking employment opportunities. Haern (2014) study the political institutional and firm governance determinants of various liquidity measure. Evidence from North Africa and the Arab Spring show that the greatest changes in political risks associated with aggregate liquidity are democratic accountability, military in politics, and law and order.

The results of this paper, which is based on updated data, increase the pressure on the state to address more actively the existing structural problems. Our research credits the point and highlights that age is a factor in the hiring and separation decision; however, the Tunisian youth find entry to the labour market mainly through small firms. Employment mobility is still greater within smaller firms, but youth have a better chance of sustaining netemployment within larger firms, which suggests that there is an opportunity to mitigate labour constraints early by tailoring education to the needs of the private sector rather than the public sector.

Addressing the concerns of the Arab Spring is a great challenge. The Middle East Monitor (2012) stated that there is scope for greater reform in states such as Egypt, Tunisia, and Syria, but it will only come about out of economic necessity. We believe the necessity should not come at a high cost, but the voice of many scholars and frustrated job seekers should be enough to place focus on research. Although this paper is one of many studies that point to 
continued struggles in Tunisia's labour market, we took a slightly different approach to understand the nature of the problem.

Firm level data consisting of 503 businesses with five workers or more operating in five sectors (construction, finance, manufacturing, services, and trade) over the period of January 2007 to December 2012 was used for a general look at the impact on hiring and separation in Tunisia. We combined this data with additional information such as employee age, employment category (top, middle, and lower management), and industrial sectors. The panel data was fitted to explain the quarterly relation between the hiring and separation rates before and after the Arab Spring. We strongly believe that our model results provide valuable insights that should be used to continue research and further engage policymakers in understanding demographic trends and the challenges faced in Tunisia's labour market. This paper narrows in on key variables and helps expose the factors that contribute to sustained job growth for segments of the country's vast population.

This paper examines the dynamics of Tunisia's labour market and quantifies hiring and separation rates ex ante and ex post the Arab Spring. Most of the results of our specified models confirmed viewpoints from previous academic papers, but also several interesting trends helped to explain more about the impacts on hiring and separation based on the estimates and correlation of various variables. For example, we found that age is generally a negative factor in hiring, which is consistent with the high level of youth unemployment. However, the underlying results in our models suggested that employees in lower age groups (18-27) are more mobile in small firms within the informal sector, but net-employment is greatest in larger firms in the formal sector. This highlights that although Tunisia's youth have a better chance of joining smaller firms, better training and development could possibly help with upward mobility and sustained net-employment in the labour market. Our views were shaped during a thorough analysis of model results, and in addition, we utilized scholarly research to form conclusions and recommendations for labour market policymakers.

We also relied on previous research to show that there is some improvement in the national labour market. It is known that even though employment at exportable sectors mainly rises when employment at importable sectors falls, the supply of labour still increased dramatically in Tunisia as women entered the labour market (Haouas, Yagoubi, Heshmati; 2005). Our previous papers highlight signs of strength, albeit very gradually. The growth in female labour force participation places further emphasis on ensuring equal opportunity and room for sustainable net-employment and upward mobility based on skill set and labour market dynamics. This paper shows that gender is less of a factor in hiring and separation, which is good, but age and level in the organization continues to have an impact on hiring and separation. This means that greater involvement in all areas of employment population combined with the right education and efficient policies should result in positive gains for all.

A more efficient policy that incentivizes training and development geared towards the private sector should provide greater opportunity for Tunisia's youth. Ours result indicate that sluggish hiring and greater separation could discourage many labour market participants. We also believe that the potential for another Arab Spring is greater without significant reform as a precautionary measure to reduce its potential negative impacts.

The structure of the paper is as follows. Section 2 briefly summarizes the relevant literature. Section 3 provides a description of the data used in the estimation. Section 4 explains the background of the models and mathematical equations. Section 5 analyses whether certain groups of employees are more exposed to difficulties caused by the Arab Spring and global economic crisis. The analysis will be distinguished by sector of activity, age of employees, 
their gender, and employment category. Lastly, Section 6 summarize this study and provides policy recommendations.

\section{Literature Review}

According to a World Development Report entitled "The Economics of the Arab Spring," the single failure of the Arab world is the absence of a private sector that is independent, competitive, and integrated with global markets (Malik and Awadallah, 2013). The forces of private and public enterprises before and after the Arab Spring are central to our study of the ultimate effect on hiring and separation rates in Tunisia. We used information provided in the World Development Report due to its use of current data and relevant policy implications. The Arab Spring came amidst what was hailed by few as the Arab renaissance, where the policy makers had taken steps to ensure economic stability in the region by shifting towards a much more active private sector, promoting privatization and increased private investments. These reforms had been in place by the 1990s and led to economic growth that had not been witnessed before. However despite these positive efforts the growth rates achieved were the lowest relative to other regions.

Private sector development is a challenge in the Arab world, yet it generates incomes independent of rent streams controlled by the state. This is an important reason why the region must overcome economic barriers that contributed to the rise of the Arab Spring (Malik and Awadallah, 2013). The Arab Spring revolutions were fuelled by poverty, unemployment, and lack of economic democracy and opportunity. Schraeder (2012) looks at the role of the international community in democracy promotion efforts abroad, including in the MENA, which were once thought to be impervious to democratic change. Karshenas et al. (2014) examine prospects for the shift from an authoritarian corporatist social policy regime to a democratic and developmental one. Trabelsi (2014) also examine the impact of political transitions on democracy, corruption and growth in the Arab Spring countries. The Arab governments had failed to recognize the lack of social protection, and the nonexistence of efficient institutions for a social dialogue among representatives of public and private partners in the market. The governments' policies had a positive impact upon a certain rich class but they did not prove to be benefiting the middle class and the poor. The youth bulge dramatically changed the demographic profile of the Middle East (Malik and Awadallah, 2013). The unemployment rates though had fallen since the 1990s, it was the women in the regions who had become more educated now and were unable to find jobs that resulted in high unemployment. Adding to the frustration of the people was the fact that the production was still stuck in the phase of low productivity thus the job opportunities were not highskilled and low paid. The young and skilled people in the region were faced with inadequate job opportunities.

The unemployment problem is also deeply rooted in the rigid local economic barriers. According to the World Development Report, 58\% of exports of (Gulf Cooperation Countries) GCC are with other GCC member countries, and is particularly limited between North Africa and the remaining parts of the Arab World. Tunisia's total exports are the second highest to Jordon in the resource-poor group, but intra-MENA exports are far below the group average. Tunisia suffers from chronic regional socioeconomic imbalance brought upon by promoting larger cities on the eastern coast, whereas central and western regions with unemployment as high as $20 \%$ are clearly forsaken by previous governments (Berhouma, 2013). The International Labour Organization also points to the volatile and low economic growth following the Arab Spring which prevents improved labour market outcomes, and has considerable implications in particular for the youth employment outlook. 
World Economic Forum (2012) and United nations Department of Economics and Social Affairs (2011) sees addressing the 100 million youth and perspective on their employment a challenge.

From 1980's to 2010, per capita income growth had slowed down to only $0.5 \%$ per year on average. According to a report from the African Development Bank, ranging between 9 and $15 \%$ the Arab region had the highest rate of unemployment in the world. This can be attributed to the job market in the region which lacks growth. Both the governments and industry exhibit low job creation. To understand these impacts requires a deeper understanding of the job market. Previous research has shown that job finding and separation rates both contribute to unemployment. However it is job finding ability that has larger influence over the fluctuations in unemployment as it is found that the separation rate does not alter much (Hall, 2006). Contrary to the general belief that, it is the workers being laid off during recession that contribute to high unemployment, it is actually the inability of the unemployed to find work or the employed to find better work opportunities that explains fluctuations in unemployment. Using US data the job to job transitions are shown to be procyclical in nature justified by a cyclical job finding rate and a-cyclical separation rate (Shimer, 2005).

Worker productivity, interest rates and wage stickiness are found to be affecting the job finding rate (Hall, 2006). In the Arab region the lack of substantial growth in wages directly contributes to the unemployment as workers are forced to work in low paying and low skilled jobs which also affects their productivity. Treating job creation and separation as endogenous variables and considering that labour productivity varies randomly, it has been concluded that the prospect of a cyclical change or shock brings about a fall in the cyclical nature of job creation and these shocks on the other hand upsurge the cyclical nature of job destruction (Mortensen and Pissarides, 1994).

Unemployment is growing rapidly, but it is certainly not exclusive to women and youth; as our study shows that age is more likely a factor in separation decisions rather than hiring, and has a positive influence on labour mobility. In another study of OECD countries, age, education and gender are found to be the main factors affecting worker hiring and separation rates. With age the hiring rates fall and in line with the Arab situation, among a few countries high separation rates are observed for youth as compared to adults (Bassanini and Marianna, 2009). The male youth unemployment rate in Tunisia was last recorded at $18.5 \%$ and it is more than three times the male adult rate of 5.7\% in North Africa (ILO, 2012a and 2012b). Hasim et al (2013) looks at the role of media of Arab Spring by presenting a gender perspective of the upheaval.

In the long run employment demands respond greatest to output, followed by changes in capital stock, and least by wages (Haouas, Yagoubi, and Heshmati; 2003). We noticed that manufacturing is a leading industry in Tunisia based on its share of employment, but it is also sensitive to seasonal factors and when connecting previous research to our latest studies, we can conclude that micro factors such as output, capital stock, and wages are considered in the hiring and separation decisions. Manufacturing increased as production becomes more skill and technology intensive, which means that business and economic growth should positively affect labour market trends.

The Arab Spring has by no means disappeared, but will continue to affect the region for many months, if not years, to come (Middle East Monitor, 2012). Unlike several other Arab countries, Egypt and Tunisia underwent relatively mild political transitions and only experienced temporary recessions, despite the collapse of the key components of foreign investment and tourism. However, the Middle East Monitor suggests that there is reason to be 
optimistic about Tunisia as smooth elections and a modest return to growth is underway; but we should remain cautious of the external environment with risks of conflict on the Libyan border. Furthermore, economic necessity suggests measures as to expand the scope for reform and to introduce greater privatization (Middle East Monitor, 2012).

Reform should also include trade liberalization which has long-run effects on employment and wages. Our previous research (Haouas, Yagoubi, Heshmati; 2005) shows that there were two different phases of employment evolution in exportable and importable sectors: weak growth until 1974, and stronger growth between 1975 and 1976. The private sector will benefit from trade liberalization which could bode well for employment. One problem is that Tunisia is not well integrated with global markets as private sector development remains a challenge. The region must overcome economic barriers especially as the demographic profile of the Middle East skews more to the growing youth bulge. There is a struggle for inclusion as physical mobility is restricted across borders. From 1996 to 2006, the labour force in the MENA grew three times as much annually as in the rest of the development world (Malik, Awadallah; 2013).

A broader look at Tunisia's labour market starts with identifying the process of adjustment in employment. This paper analyses employment mobility and the factors that contribute to hiring and separation based on firm size. We noticed that the lower age groups are more mobile across the spectrum, but have a greater chance of sustaining net-employment with larger firms. Our previous study (Haouas, Yagoubi, and Heshmati, 2003; Heshmati and Haouas, 2011) which uses industry and time specific data to determine factors affecting adjustment in employment and labour use efficiency provides a strong background to this analysis.

\section{The Data}

The data used in this study was collected from the Social Security Fund (CNSS) of Tunisia on a large sample of 503 firms with five workers and more, totalling 12,072 observations between January 2007 and December 2012 on a quarterly basis. The focus has been on the employment status in different sectors, such as Construction, Finance, Manufacturing, Services and Trade. The main indicators consist of the number of hiring, number of separations and total employment effects. In addition, the analysis includes the top, middle, and lower manager employment categories; gender; age cohorts (from 18-24 up to 55-64), formal and informal industries, labour mobility, and net-employment and time trend. Age, gender, age cohort and managerial levels are expressed in shares of total, while mobility is defined as sum of hiring and separation and net-employment is the difference between hiring and separation. An employee who will find a job in the firm at time $t$ is counted in the total number of hiring variable, while those leaving the firm at time $t$, will be included in the total number of separation (Haouas et al., 2012 and Brosius, 2011). For the workers who are not included in the hiring or separation categories we identified three situations: they work in another firm; they start their own business, or leave the workforce as unemployed. However, the information regarding these three options is not available in the CNSS of Tunisia. Ultimately, the data was used to explain the measurable impact of the Arab Spring on hiring and separation rates.

The summary statistics of the data was obtained through univariate procedures and is reported in Table 1 . The mean for both indicators, number of hiring and number of separation is similar-3.513, respectively 3.510, which means that on average, the number of employees who would find a job in the firm at time $t$ is equal with the number of workers that would 
leave the firm at time t. The average firm level employment is 118, with most part of the employment forces in lower management (77.7\%, on average), occupied by males and female (73.8\%, respectively $44.6 \%$, on average) with the highest concentration within the $45-54$ age cohort (36.5, on average). The finance, manufacturing, and trade sectors averaged the highest employee count.

\section{Insert Table 1 here}

The summary statistics of the data show large variations in hiring and separation of firms across different industrial sectors, sizes and over time and seasons. The different rates shares by gender and managerial categories greatly differ as well. Analysing the value of Pearson correlation coefficients among the variables reported in Table 2 show consistent results, as follows: the hiring rate is negatively correlated with the separation rate $(-0.065)$; the top management has a negative correlation with the hiring-rate $(-0.046)$, while both middle and low management are positively correlated with the same indicator $(0.0046$, respectively 0.046). We identified a positive correlation between the separation rate and the management at all levels. Female employment is negatively correlated with the hiring-rate $(-0.009)$, while there is a strong negative correlation $(-0.084,-0.087$ and -0.082$)$ among the $18-24,35-44,45-$ 54 age cohorts and net-employment.

\section{Insert Table 2 here}

We concluded that perhaps top management employees keep their position for a longer period, thus, given the negative correlation with the hiring rate it is an interesting contrast to the strong correlation between males and mobility in the 18-24 age cohorts. This evidence supports the fact that both Tunisian youth and the 35-54 age segments face an ongoing struggle to remain in the labour market; in addition, females are less likely to be hired. The statistical results obtained are consistent with the market realities: in 2013, the unemployment rate among youth with a university degree has doubled since 2005, numbers explained by the vulnerable political and economic situation.

\section{Models and Estimation Procedure}

The labour market outcome (Y) is determined by individual $(\mathrm{X})$, industry $(\mathrm{Z})$, labour market (M) characteristics and the state of technology $(\mathrm{T})$. This theoretical model is written as:

$$
\mathrm{Y}=\mathrm{f}(\mathrm{X}, \mathrm{Z}, \mathrm{M}, \mathrm{T})
$$

We constructed an integrated database in order to offer a better comparison of the factors contributing to hiring and separation rates in Tunisia before and after the Arab Spring. We worked with six main models including outcomes of hiring and separation levels, hiring and separation rates, mobility, and net-employment. Each model was estimated five times using pooled data, small firms (less than 55 employees, which is the median of the data), large firms (55 and more employees), formal firms (manufacturing, trade, and finance), and informal firms (construction and services assuming they can absorb informal activities easier). This means a total of 30 models based on the fixed effects estimation method with robust standard errors controlling for all possible firm, industry and labour market heterogeneity effects. The 6 basic models with different dependent variables are not nested, but for each model the pooled and those size and formal related are nested and can be tested to establish possible response heterogeneity. The result from the comprehensive sensitivity analysis is expected to shed lights on actual labour market conditions in Tunisia and its evolution during the global economic recession and Arab Spring events. 
Since there were too many model combinations, we decided to drop several and focus on the remaining important ones with the best fit considering the trade-off between $\mathrm{R}^{2}$ and the number of estimated parameters. The trade-off is a richer model specification that produces a higher $\mathrm{R}^{2}$ value; however, many parameters can also reduce the usefulness of the model as a result of over-parameterization and multicollinearity. The tables included in this paper display the main results of our study.

We specified and estimated level models of hiring and separation, but then changed the specification to hiring and separation rates (shares) in order to emphasize the best way to model hiring and separation rates. In specifying the mobility and net-employment models, we looked at level and shares of the total hiring and separation or their difference. We continued to explore the firm size and formality of sectors. The size classification is based on number of employees; for the threshold, we use median, while for the formal informal we have no direct information. We treat sectors with less tied regulations as informal sectors. Several models are non-nested but jointly provide useful information about the Tunisian labour market and on how to improve the employment conditions in particular for the youth.

\subsection{Hiring and separation level models}

As previously explained, an employee is included in the total number of hiring if he/she will find a job in the firm at time $t$. For those leaving the firm at time $t$, they will be counted in the total number of separation (Haouas et al., 2012 and Brosius, 2011).

The number of generic firm's hired employees $\left(H_{i t}\right)$ is estimated by the subsequent regression Model 1:

$$
\begin{aligned}
H_{i t}= & \alpha+\beta E_{i t}+\gamma_{2} M M_{i t}+\gamma_{3} T M_{i t}+\delta_{1} M_{i t}+\xi_{2} A 2_{i t}+\xi_{3} A 3_{i t}+\xi_{4} A 4_{i t}+\xi_{5} A 5_{i t} \\
& +\varphi_{2} S 2_{i}+\varphi_{3} S 3_{i}+\varphi_{4} S 4_{i}+\varphi_{5} S 5_{i}+\tau_{2} Y 2_{t}+\tau_{3} Y 3_{t}+\tau_{4} Y 4_{t}+\tau_{5} Y 5_{t}+\tau_{6} Y 6_{t} \\
& +v_{2} Q 2_{t}+v_{3} Q 3_{t}+v_{4} Q 4_{t}+\psi A S_{t}+\varepsilon_{i t},
\end{aligned}
$$

where $E$ is number of employees representing the firm size; $i$ and t refer to firm and quarter time periods; $M M$ and $T M$ are numbers of medium and top-level managers at time; $M$ represents the number of male employees; A2- $A 5$ refer to the number of employees aged cohorts 25-34, 35-44, 45-54 and 55-64; $S 2$ to $S 5$ are dummy variables identifying the sectors where firms belong to; Y2 to $Y 6$ are a series of year-related dummies; $Q 2$ to $Q 4$ are a series of quarter-related dummies; $A S$ is a dummy related to period included in the first three quarters of 2011 capturing the Arab Spring effect; and finally $\varepsilon$ is a random error term, assumed to be normally distributed, with mean zero and constant variance showing no autocorrelation and no heteroskedasticity. The variables $T M, F, A 1, S 1, Y 1$ and $Q 1$ are omitted to serve as reference for remaining categories in the groups.

A similar model with the same regressors, is applied for the number of generic firm i's separation employees at time $t\left(F_{i t}\right)$ labelled as Model 2:

$$
\begin{aligned}
F_{i t} & =\alpha+\beta E_{i t}+\gamma_{2} M M_{i t}+\gamma_{3} T M_{i t}+\delta_{1} M_{i t}+\xi_{2} A 2_{i t}+\xi_{3} A 3_{i t}+\xi_{4} A 4_{i t}+\xi_{5} A 5_{i t} \\
& +\varphi_{2} S 2_{i}+\varphi_{3} S 3_{i}+\varphi_{4} S 4_{i}+\varphi_{5} S 5_{i}+\tau_{2} Y 2_{t}+\tau_{3} Y 3_{t}+\tau_{4} Y 4_{t}+\tau_{5} Y 5_{t}+\tau_{6} Y 6_{t} \\
& +v_{2} Q 2_{t}+v_{3} Q 3_{t}+v_{4} Q 4_{t}+\psi A S_{t}+\varepsilon_{i t},
\end{aligned}
$$

\subsection{Hiring and separation rate models}

The models above was based on the levels of hiring and separations. The hiring rate as share of employment has been computed by the following formula: 


$$
H R_{i t}=H_{i t} / E_{i t}(\mathrm{i}=1, \ldots, 503) ;\left(\mathrm{t}=2007_{\mathrm{q} 1}, \ldots, 2012_{\mathrm{q} 4}\right)
$$

where $H R_{\mathrm{it}}$ is the hiring rate, $H_{i t}$ is the number of hiring and $E_{i t}$ represents the employment size of the firm $i$ at the time $t$, representing quarters, $q$.

The number of generic firm i's employees hired per total number of employees in a given quarter at time $t$ is estimated by the subsequent regression Model 3:

$$
\begin{aligned}
H R_{i t} & =\alpha+\beta E_{i t}+\gamma_{1} M M_{i t}+\gamma_{2} T M_{i t}+\delta_{1} M_{i t}+\xi_{2} A 2_{i t}+\xi_{3} A 3_{i t}+\xi_{4} A 4_{i t}+\xi_{5} A 5_{i t} \\
& +\varphi_{2} S 2_{i}+\varphi_{3} S 3_{i}+\varphi_{4} S 4_{i}+\varphi_{5} S 5_{i}+\tau_{2} Y 2_{t}+\tau_{3} Y 3_{t}+\tau_{4} Y 4_{t}+\tau_{5} Y 5_{t}+\tau_{6} Y 6_{t} \\
& +v_{2} Q 2_{t}+v_{3} Q 3_{t}+v_{4} Q 4_{t}+\psi A S_{t}+\varepsilon_{i t}
\end{aligned}
$$

where the already introduced variables have the same construction and meaning as those described above. Managerial, age cohorts and male variables are defined as shares total. A similar model is also used to estimate the number of generic firm $i$ 's employee separation rate per total number of employee $\left(F R_{i t}=F_{i t} / E_{i t}\right)$ specified as Model 4:

$$
\begin{aligned}
F R_{i t} & =\alpha+\beta E_{i t}+\gamma_{1} M M_{i t}+\gamma_{2} T M_{i t}+\delta_{1} M_{i t}+\xi_{2} A 2_{i t}+\xi_{3} A 3_{i t}+\xi_{4} A 4_{i t}+\xi_{5} A 5_{i t} \\
& +\varphi_{2} S 2_{i}+\varphi_{3} S 3_{i}+\varphi_{4} S 4_{i}+\varphi_{5} S 5_{i}+\tau_{2} Y 2_{t}+\tau_{3} Y 3_{t}+\tau_{4} Y 4_{t}+\tau_{5} Y 5_{t}+\tau_{6} Y 6_{t} \\
& +v_{2} Q 2_{t}+v_{3} Q 3_{t}+v_{4} Q 4_{t}+\psi A S_{t}+\varepsilon_{i t}
\end{aligned}
$$

\subsection{Mobility and net-employment models}

These models, with the same set of regressors described above, are also used to estimate the total amount of the generic firm i's mobility $\left(M o b_{i t}=H_{i t}+F_{i t}\right)$ and net-employment $\left(N E_{i t}=\right.$ $\left.H_{i t}-F_{i t}\right)$ at time $t$. The models 5 and 6 are specified, respectively:

$$
\begin{aligned}
& M o b_{i t}=\alpha+\beta E_{i t}+\gamma_{1} M M_{i t}+\gamma_{2} T M_{i t}+\delta_{1} M_{i t}+\xi_{2} A 2_{i t}+\xi_{3} A 3_{i t}+\xi_{4} A 4_{i t}+\xi_{5} A 5_{i t} \\
& \quad+\varphi_{2} S 2_{i}+\varphi_{3} S 3_{i}+\varphi_{4} S 4_{i}+\varphi_{5} S 5_{i}+\tau_{2} Y 2_{t}+\tau_{3} Y 3_{t}+\tau_{4} Y 4_{t}+\tau_{5} Y 5_{t}+\tau_{6} Y 6_{t} \\
& \quad+v_{2} Q 2_{t}+v_{3} Q 3_{t}+v_{4} Q 4_{t}+\psi A S_{t}+\varepsilon_{i t} ; \\
& \\
& N E_{i t}=\alpha+\beta E_{i t}+\gamma_{1} M M_{i t}+\gamma_{2} T M_{i t}+\delta_{1} M_{i t}+\xi_{2} A 2_{i t}+\xi_{3} A 3_{i t}+\xi_{4} A 4_{i t}+\xi_{5} A 5_{i t} \\
& \quad+\varphi_{2} S 2_{i}+\varphi_{3} S 3_{i}+\varphi_{4} S 4_{i}+\varphi_{5} S 5_{i}+\tau_{2} Y 2_{t}+\tau_{3} Y 3_{t}+\tau_{4} Y 4_{t}+\tau_{5} Y 5_{t}+\tau_{6} Y 6_{t} \\
& \quad+v_{2} Q 2_{t}+v_{3} Q 3_{t}+v_{4} Q 4_{t}+\psi A S_{t}+\varepsilon_{i t} ;
\end{aligned}
$$

\subsection{Mobility and net-employment models by other characteristics}

The estimations are conducted by two main characteristics, namely size of firms and formal/informal character of the industries. The last two models of mobility and netemployment (5 and 6) are also used to forecast firms' mobility and net-employment each in two subgroups, created based on the size of companies and formal/informal nature of the industry sector. One model is estimated among the companies with less than 55 (median) employees and one on those having 55 or more employees. Considering formal/informal character of the industry sectors, we classified finance, trade, and manufacturing sectors as formal, while service and constructions sectors are potential informal sectors. The last four models are labelled as models 7 and 8 and 9 and 10, respectively. The set of explanatory variables are constant across different model specifications.

\section{Analysis of the Results}




\subsection{Hiring and separation level models}

Table 3.A displays the results of the level models: hiring and separation, with parameter estimates and standard errors. The models explain $89.6 \%$ and $74.8 \%$ of variations in hiring and separation, respectively. The employment size of the firm is positively correlated with hiring but is statistically insignificant or unrelated to separation. The results show that gender, represented by male, is a statistically significant variable in both hiring and separation models. The positive sign suggests that males are more often hired and separated compared to their female counterparts. Given the results, the gender factor leads to a unique conclusion namely the strong impact of this indicator in the hiring model. The analysis shows some interesting findings in the case of other variables as well that could help to explain hiring and separation patterns in greater detail.

\section{Insert Table 3.A here}

The hiring model results indicate that, although generally, age is a negative factor in hiring, it has a positive impact on separation. The reference age cohort is the 18-24 segment. We conclude that employers are more likely to consider age below 35 as a determinant factor in hiring. However, age seems to be an insignificant factor in the separation decision. The latter could be a variable that is affected by labour market regulations, committed employment contract time and the level of experience in the field. Our analysis question is whether employers are willing to dismiss the older workers in order to trigger an effective increase in mobility that will open new opportunities for youth to establish a sustainable presence in the labour market. We also found that the manufacturing sector has a more negative effect on hiring compared with the reference sector of finance, despite occupying a large share of total employment. The result shows that both hiring and separation are much lower after the start of the Arab Spring. Therefore, the data suggests that Tunisia's labour market is still vulnerable, but a deeper analysis on the raw data is needed to discover the reasons behind hiring and separation ex ante and ex post the Arab Spring.

The hiring and separation behaviours of middle and top managements are different compared to those of the low management category. The hiring is favourable to middle but not favourable to top management relative to the low management category. Separation is positively correlated with the professional level. Despite yearly variations, the dummies registered every year show less hiring and greater separations over time compared to the base year (2007). Similar variation and patterns are found in relation to seasonal dummies.

\subsection{Hiring and separation rate models}

Table 3.B displays the results of the employment share models: hiring and separation rates. These models performances in explaining variations in hiring and separation rates are 46.7 and 34.0, respectively. Compared with the separation level model, the separation rate model has a much lower variation measured as root mean square error. Here, we note that the size of firms has positive effects on both outcomes. When considering employment category, middle category is negatively associated with hiring, compared with low category, but no effects are found in relation with separation. We also note that the second age cohorts share (25-34 age segment) has a higher estimate in the hiring model compared to that of the separation model, which is not significant. The age cohort effects are in general very similar to those registered in the level models, with negative hiring for ages above 35 and positive association between age and separation rate.

Insert Table 3.B here 
The hiring rate model also returned negative estimates for the yearly dummy variables compared to the reference year of 2007, while separation rates were all positive and statistically significant. The negative hiring rate and the positive separation estimates are declining over quarters. This indicates systematic seasonal flow in employment or variations in hiring and separation patterns; moreover, hiring tapers off during the fourth quarter as explained in both share models.

All 4 industry sectors show lower hiring rate compared with the reference sector of finance. None of the industry effects is significant in terms of separation rates. This shows evidence of industry heterogeneity in the hiring rate model, which suggests that some industries are more vulnerable to changes in the labour market, given its negative estimate in the original hiring level model in Table 3.A We also realized that the Arab Spring variable was negative in the hiring rate model, but unlike in the level model case, a positive estimate in the separation rate model.

\subsection{Mobility and net-employment models}

The estimation results for the labour mobility and net-employment models are reported in Table 3.C. The fit of the model measured by $\mathrm{R}^{2}$ is much higher in the net-employment model compared with the mobility model, 0.547 vs. 0.1274 , although the model variances are similar. The size of firms measured as number of employees has positive effects on both mobility and net-employment. Considering the employment type variables, we obtained a similar sign patterns as those of the level model. The evidence shows that middle management has a positive estimate in the mobility model, but a negative estimate in the netemployment effect model. The top management share estimate is negative in mobility, but positive in net-employment, which suggests that although the upper management group is relatively settled in the labour market, it still has effects on broader net-employment. In addition, the middle management has an impact on mobility.

\section{Insert Table 3.C here}

It is interesting that the age 2 and age 3 cohorts' shares had positive estimates in the mobility model, but the age4 and age5 cohort shares had negative estimates in the same model. Lower age groups tend to be more flexible, which was also explained in our previous models. However, Table 3.C shows that lower age cohorts, especially age3, have higher negative estimates in the net-employment effect model.

The yearly dummies for mobility indicate consistent results with our previous hiring level and rate models, in which mobility is reduced over time. On the contrary, the netemployment showed a changed sign from mainly positive to negative, interpreted as lower net-employment between 2008 and 2012 compared to 2007. The findings of the previous model show that hiring tapers off during the fourth quarter, which is why the estimate was positive in the mobility model, but negative in the net-employment model. The explanation relates to the effect of the seasonal trends. Meanwhile, the negative industry sector estimates suggest greater mobility in the finance sector.

\subsection{Mobility by net-employment models by firm size}

The results of the mobility and net-employment models by firm size, small and large, is displayed in Table 3.D. Mobility and net-employment vary across different characteristics of the employees and other determinants. Comparing the results by firm size, we get a better sense of labour market conditions, which can be influenced by the business cycle. Generally, 
we hypothesized that smaller firms are more vulnerable to changes in the business cycle, which can have a negative effect on their net-employment and mobility in the labour market if the conditions get worse. After the 2008 global recession and heightened structural issues that contributed to the rise of the Arab Spring in 2010, we expected that the results would reflect these fundamental shifts in Tunisia's labour market. For small size businesses, mobility decreases with the number of employees but an increase in the number of employees determines an upward trend of net-employment. The opposite holds for large size.

\section{Insert Table 3.D here}

The share of top management has a positive estimate in the small size net-employment model, a greater estimate in the large size mobility model, but a negative and insignificant estimate within the large size net-employment model. The results suggest that although top management is usually stable as explained in previous models, mobility is greater in large size firms for the top management group. We suspect that opportunities for top-level management are higher in larger firms than smaller firms, which could influence mobility.

The lowest two age cohorts' positive estimates are associated to the small size mobility and net-employment models. However, despite having positive estimates in the large size mobility model, the two lower age cohorts had negative estimates in the large size netemployment model. The remaining higher age cohorts' shares returned negative estimates in all models when comparing firm sizes. The results suggest that lower age groups have a greater share of mobility and net-employment in small firm size class, but not so much in the case of large size firms. Given that further details would be provided later, we conclude that younger workers might benefit more of the available opportunities within smaller firms and entrepreneurial ventures that will train and develop a skilled workforce. As a result, they will be qualified for higher-level opportunities in larger private sector firms.

Quarterly and yearly dummy variables were largely consistent with those from our previous models, showing little changes. Mobility and net-employment by size are negatively associated with time. The picture of small size firm mobility is different. However, given the sector breakdown we found that mobility was generally greater in larger firms relative to smaller firms. In comparison with the finance sector, the service area had a negative estimate in the small size mobility model, but the estimate for small size net-employment model was positive. The estimates for large size service firms are opposite. The evidence shows a different scenario for the remaining sectors: trade, construction, and manufacturing.

Additionally, despite large variations in fit of the models lower for mobility and higher for net-employment, the standard robust errors were largely the same across all models when comparing mobility and net-employment by size. The Arab Spring has a positive effect on mobility and a negative effect on net-employment of small size firms. However, for the large size firms, both have declined ex post the Arab Spring.

\subsection{Mobility and net-employment models by formal/informal sectors}

Table 3.E displays the summary results of the mobility and net-employment models by formal/informal sectors classification. Formal sectors are monitored by all forms of government regulations and included in GNP, whereas the informal sector operates in the underground economy - often with employees who do not benefit of job security, where participation could be influenced by the desire to avoid regulation and taxation (Williams, 2005). Assaad (1993) view informal institutions to be significantly important in shaping the labour market relations. It is important to compare the results of both formal and informal sectors in order to get a better understanding of labour market conditions that often is not 
reported. We considered the possibility that hiring and separation levels and rates and mobility and net-employment only reflect one side of the economy; given the focus on firm size in the previous model, we determined that the formal and informal sectors would provide greater insight into employment trends during the Arab Spring. Formal and informal are distinguished on an ad hoc basis by separating the industries according to their actual market characteristics. This approach is used in the absence of data regarding the formal nature of the firms operation.

\section{Insert Table 3.E here}

We do not find much difference in mobility and net-employment by formal nature of firms in regards with the number of employees. The younger age cohorts (age2 and age3) have positive estimates in the formal mobility model, but age 3 cohort has a negative estimate in the formal net-employment model. Age2 cohort had the only positive estimate in the formal net-employment model, whereas age4 cohort had negative estimates in both formal mobility and net-employment effect. While mobility is positive in the informal sectors for all age cohorts, in the informal sector the net-employment effect is negative. The age2 cohort received the highest informal mobility estimate (0.169). The results were mixed, but suggest that the net-employment effect is greater in formal sectors for the younger age cohorts. While mobility is better in the informal sector, all age cohorts would benefit of a positive impact on net-employment in the formal sector.

All yearly and quarterly dummies signs were consistent with our previous models, which point out too little change in mobility and net-employment from 2008 to 2012. Seasonal factors were less noticeable in the results, but quarters 2, 3 and 4 had a positive estimate in the informal sector mobility model. Arab Spring was also positive in the formal and informal sectors mobility models suggesting a negative mobility and net-employment over time compared with the base year of 2007.

Furthermore, we could also consider that separation is greater in the informal sector, which could help firms adapt to changes in the business cycle at the expense of workers. This could cause some discrepancy in quarterly trends and other variables, so we considered the data as additional evidence outside of our core models described in the previous sub-sections.

\section{Summary and Recommendations}

One fact that remained consistent in all of our models is that hiring was relatively little changed from 2008 to 2012, which suggests that Tunisia still has lingering effects from the financial crisis and Arab Spring that will add further weight on the country's labour market. We continue to believe that Tunisians will need to see significant reform or else further frustration with labour market constraints will lead to renewed protests, and similar structural issues from the Arab Spring will come to light once again. Our results indicate that there are significant challenges faced by Tunisian youth that can be mitigated through efficient policy action that incentivizes training and development that is geared towards the private sector.

The background problem is that labour market conditions that influenced the rise of the Arab Spring continue to weigh on the potential employment gains. Even though Tunisia's labour market is improving, it is still performing below potential as several groups like the youth population continue to struggle with sustained job placement. We know that targeted reform helps to address these concerns and provides support for sustainable employment growth in the labour market. Adjustment was faster during liberalization from 1986 to 1994 and post liberalization from 1995 to 1996 (7.5\%). Slower adjustment (6.8\%) from 1972 to 1985 during 
pre-liberalization times show that there is much room to gain from efficient economic policy (Haouas, Yagoubi, and Heshmati; 2003).

One highlight of our results was that age is a negative factor in hiring, and a positive impact on separation. We view that employers are more likely to consider age as a factor in hiring and separation decisions. This paper further implies that age can represent years of experience, skill set and training. The results suggest that age is still a factor that is less in favour with the younger generation of job seekers, while gender is less of a factor especially as female labour force participation increases. We still saw evidence that females face some difficulties in the job market, but the additional labour supply will help especially with more efficient policy to match skill sets with private sector demand.

We also noticed that top management is more mobile in larger firms, which could stem from increased opportunities contributing to upward mobility in the corporate sector. Contrary to the top age group, lower age groups are more mobile in smaller firms, where we see most of the entry to the labour market occurring as youth gain placement with start-ups and small enterprises. The mobility and separation among firms with limited resources could be a challenge to policy that focuses on training and continued efforts to retain employees. We suggest that a revamp of the educational framework is needed in order to shift focus towards private sector employment upon graduation. This could enable many younger Tunisians to engage in entrepreneurial ventures of their own and thereby sustain hiring and continue to grow and develop into larger firms where they will eventually sustain net-employment.

The fourth quarter continued to show a seasonality effect within our results, as hiring starts to taper off in many sectors. We also noticed that mobility is positive in the informal sector, but net-employment effect is greater in the formal sector. Seasonality was less noticeable in the formal vs. informal sector analysis. Our results provide evidence of the reasons and factors behind continued struggles in Tunisia's labour market, which demand more policy action.

Tunisia will need to focus on balancing its economy to avoid heavy seasonal impact on hiring in sectors like manufacturing and services. Our results show that net-employment is greater among large firms in the formal sector which helps to increase employment in lower age cohorts. We learned that lower age cohorts are more mobile, but also face greater separation as the decision to continue education is likely to result in extra time to avoid the feeling of discouragement in the competitive labour market. Tunisian youth will need to be trained early and continue acquiring developing skills that are in line with demand through coops and internships that could lead to sustainable positive net-employment.

We view the Tunisia's government response to high unemployment resulting from the financial crisis in 2008 and Arab Spring in 2012 was not enough. A higher wage bill, job creation programs, and rising subsidies in response to increasing social welfare demands were welcomed, but the trade-off of higher government spending swelled the country's fiscal deficit in 2012. By using the results in this paper, Tunisia's government can focus on allocating resources more efficiently based on the direct impacts that result in higher or lower estimates in hiring and separation rates.

There is evidence that the unemployment rate of educated youth is higher than those provided in official statistics, increasing from $14.8 \%$ in 2005 to $21.6 \%$ in 2008 . Our previous study found that in Tunisia, unemployment is essentially a youth issue (Haouas, Sayre and Yahoubi; 2012). The results in this paper show that age generally is a negative factor in hiring, and has a positive impact on separation. We conclude that employers are more likely to consider age as a factor in separation, which could lead to further discouragement. 
Young people who delay labour market entry by way of continuing education are perhaps discouraged by low wages. In addition, emigration of skilled workers that historically reduced labour market pressures are no doubt concerning (Haouas, Yagoubi, and Salvino; 2012). In fact, a recent Gallup study conducted by Abu Dhabi Gallop Center shows the growing public distrust in the Tunisian government. As Tunisia's GDP continued to show small positive growth rate in recent years, Tunisians' life evaluations continued to plummet by 10\% from 2008 to 2010 compared to an approximate 1\% rise in GDP per capita over the same time period. Survey data also showed a significant lack of trust in government to provide basic services and infrastructure. The findings of the Gallup which polled 1,000 Tunisian nationals should be sufficient reason to truly get to the heart of the matter.

Sustainable public policy action starts with an in depth study of the structural problems that led up to the Arab Spring, as well as the impact of the actual event on hiring and separation rates. We will see if more efforts are required to efficiently expand employment opportunity for the youth, while reducing the strain of public sector crowd out. This will ease the constraints of an impatient majority in the labour force and thereby allow the private sector to organically break away from the recessionary past and increase its recruitment efforts to attract skilful talents. It is crucial for the new government to utilize the research presented in our study to address the concerns of the people of Tunisia who have a justified high expectations.

\section{References}

African Development Bank, (2012), "Jobs, Justice and the Arab Spring: Inclusive Growth in North Africa”, North Africa Operations Department (ORNA), pp. 1-112.

Assaad, R. (1993), "Formal and informal Institutions in the Labor Market with Applications to the Construction Sector in Egypt”, World Development, 21(6), 925-939.

Bassanini, A. and P. Marianna, (2009), "Looking Inside the Perpetual-Motion Machine: Job and Worker Flows in OECD Countries”,

Berhouma, M. (2013), "The Arab Spring in Tunisia: Urgent Plea for a Public Health System Revolution." World Neurosurgery, 80(3), 260-263.

Brosius, J. (2011), L’impact de la crise économique sur l'emploi au Luxembourg, CEPS/INSTEAD, Working Paper, No. 8.

Chiraz, R. and M. Firoui (2014), "The impact of Inflation after the Revolution in Tunisia”, Procedia - Social and Behavioral Sciences, 109(8), 246-249.

Haern, B. (2014), “The Political Institutional and Firm Governance Determinants of Liquidity: Evidence from North Africa and the Arab Spring”, Journal of International Financial Markets, Institutions and Money, 31, 127-158.

Hall, R.E. (2006), “Job Loss, Job Finding, and Unemployment in the U.S. Economy over the Past Fifty Years,” in Mark Gertler and Kenneth Rogoff, eds., NBER Macroeconomics Annual 2005, Cambridge, MA: MIT Press, pp. 101-37

Haouas, I., M. Yagoubi and S. Salvino (2012), “The Effect of Financial Crisis on Hiring and Separation Rates: Evidence from Tunisian Labour Market”, ERF Working Paper No. 720, pp. 1-19. 
Haouas, I., E. Sayre, and M. Yahoubi (2012), "Youth Unemployment in Tunisia: Underlying Trends and an Evaluation of Policy Responses", International Research Journal of Finance and Economics, Issue 115, October 2012.

Haouas. I, M. Yagoubi, and A. Heshmati (2005), “The Impact of Trade Liberalization on Employment and Wages in Tunisia Industries.” Journal of International Development, 17 (4), 527-551.

Haouas, I., M. Yagoubi, and A. Heshmati (2003), "Labor-Use Efficiency in Tunisian Manufacturing Industries." Review of Middle East Economic and Finance, 1(3), 195214.

Hasim M.S., S.R.H. Tibek Z. Arifin, A. Salman and A.I.M. Koni (2014), "Gender Perspective on the Arab Spring”, Procedia - Social and Behavioral Sciences, 102(22), 236-241.

Hassine, N.B. (2015), “Economic Inequality in the Arab Region”, World Development, 66, 532-556.

Heshmati, A., and I. Haouas (2011), "Employment Efficiency and Production Risk in the Tunisian Manufacturing Industries.”, ERF Working Paper No. 602, 1-31.

International Labour Organization (ILO) (2012a), “Global Employment Trends 2012: Preventing a deeper job crisis”, Geneva, pp. 1-121.

International Labour Organization (ILO) (2012b), “Global Employment Trends for Youth”, Geneva, pp. 1-57.

Karshenas, M., V.M. Moghadam and R. Alami (2014), "Social Policy after the Arab Spring: States and Social Rights in the MENA Region”, World Development, 64, 726-739.

Malik, A. and B. Awadallah (2013), "The Economics of the Arab Spring." World Development, 45, 296-313.

Middle East Monitor, (2012), "Arab Spring One Year On: Assessing the Transition", Economic Outlook, The Gulf, April. Available on: www.meamonitor.com.

Mortensen, D.T. and C.A. Pissarides (1994), "Job Creation and Job Destruction in the Theory of Unemployment,” Review of Economic Studies, 61(3), 397-415.

Schraeder, P.J. (2012), “Tunisia’s Jasmine Revolution \& the Arab Spring: Implications for Institutional Intervention”, Orbis, 56(4), 662-675.

Shimer, R. (2005), "The Cyclicality of Hires, Separations, and Job-to-Job Transitions," Federal Reserve Bank of St. Louis Review, 87(4), 493-507.

Trabelsi, M.A. (2014), "Post-Political Transition in Arab Spring Countries: The Challenges”, Procedia - Social and Behavioral Sciences, 109(8), 250-256.

Tzannatos, Z. (2010), L'impact de la crise financière sur l'emploi dans la région méditerranéenne: l'histoire de deux rive, Crise économique, pp. 34-40. Available on: http://www.iemed.org/anuari/2010/farticles/Tzannatos_impact_fr.pdf

United Nations Department of Economic and Social Affairs (UN DESA), (2011),"Youth Employment: Youth Perspectives on the Pursuit of Decent Work in Changing Times", World Youth Report.

Williams, C.C. (2005). A Commodified World?: Mapping the limits of capitalism. London: Zed Books. pp. 73, 74. 
World Economic Forum (WEF) (2012), "Addressing the 100 Million Youth Challenge: Perspectives on Youth Employment in the Arab World in 2012”. Regional Agenda, pp. $1-40$. 


\section{APPENDIX}

Table 1. Summary statistics of the Tunisian Labour Market, 2007- 2012, 12,072 observations.

\begin{tabular}{|c|c|c|c|c|c|}
\hline Variable & Definitions & Mean & Std Dev & Minimum & Maximum \\
\hline hiring* & Hiring & 3.51 & $4.3<$ & 0.000 & 43.000 \\
\hline separation* & Separation & 3.510 & 5.425 & 0.000 & 121.000 \\
\hline employee & Employees & $118.3^{\complement}$ & $126.3 t$ & 2.000 & 604.000 \\
\hline lowman & Low management & $77.6 t$ & 88.81 & 0.000 & 443.000 \\
\hline midman & Middle management & 29.41 & 33.0 단 & 0.000 & 254.000 \\
\hline topman & Top management & $11.2 t$ & $9.0=$ & 0.000 & 92.000 \\
\hline male & Male number & $73.7 t$ & $97.2 c$ & 2.000 & 584.000 \\
\hline female & Female number & 44.5; & $60.7=$ & 0.000 & 432.000 \\
\hline age1824 & Age 18-24 number & 13.5; & $15.1 \mathrm{C}$ & 3.000 & 173.000 \\
\hline age2534 & Age 25-34 number & $22.9 €$ & 24.62 & 0.000 & 212.000 \\
\hline age3544 & Age 35-44 number & $33.5 ;$ & $36.6 c$ & 1.000 & 222.000 \\
\hline age4554 & Age 45-54 number & 36.5 & $40.1<$ & 1.000 & 182.000 \\
\hline age5564 & Age 55-64 number & $11.6 r$ & $12.6 \mathrm{c}$ & 0.000 & 90.000 \\
\hline hirerate* & Hiring rate & $0.0_{2}^{r}$ & 0.02 & 0.000 & 0.333 \\
\hline separate* & Separation rate & 0.0 & 0.02 & 0.000 & 0.500 \\
\hline mobility* & Mobility & $0.0^{\mathrm{c}}$ & 0.02 & 0.000 & 0.500 \\
\hline netemply* & Net-employment & 0.06 & 0.0 & -0.500 & 0.333 \\
\hline lowshare & Low management rate & $0.5 \varepsilon$ & $0.2=$ & 0.000 & 0.946 \\
\hline midshare & Middle management rate & $0.2<$ & $0.0 \varepsilon$ & 0.000 & 0.556 \\
\hline topshare & Top management rate & $0.1 t$ & $0.1 \epsilon$ & 0.000 & 0.750 \\
\hline malshare & Male share & 0.5 & 0.21 & 0.116 & 1.000 \\
\hline femshare & Female share & 0.4\llcorner & 0.21 & 0.000 & 0.884 \\
\hline age1share & Age 18-24 share & 0.11 & $0.0^{-}$ & -0.088 & 0.800 \\
\hline age2share & Age 25-34 share & 0.2( & 0.07 & 0.000 & 0.685 \\
\hline age3share & Age 35-44 share & $0.2 ;$ & 0.02 & 0.091 & 0.500 \\
\hline age4share & Age 45-54 share & 0.2 & $0.0=$ & 0.070 & 0.500 \\
\hline age5share & Age 55-64 share & 0.11 & $0.0 €$ & 0.000 & 0.750 \\
\hline trend & Quarterly time trend & 37.5( & 17.11 & 11.000 & 64.000 \\
\hline
\end{tabular}

Note: * dependent variables 
Table 2: Pearson's Correlation Coefficients / p-values, 12,072 observations

\begin{tabular}{|c|c|c|c|c|c|c|c|c|c|c|c|c|c|c|c|c|c|c|}
\hline \multicolumn{19}{|c|}{ Prob $>|r|$ under H0: Rho $=0$} \\
\hline & hiring & separate & hirerate & seprate & mobility & netemply & employee & lowman & midman & topman & male & female & age1824 & age2534 & age3544 & age4554 & age5564 & trend \\
\hline hiring & 1.0000 & & & & & & & & & & & & & & & & & \\
\hline \multirow[t]{2}{*}{ separate } & 0.6210 & 1.0000 & & & & & & & & & & & & & & & & \\
\hline & $<.0001$ & & & & & & & & & & & & & & & & & \\
\hline \multirow[t]{2}{*}{ hirerate } & 0.2794 & -0.0654 & 1.0000 & & & & & & & & & & & & & & & \\
\hline & $<.0001$ & $<.0001$ & & & & & & & & & & & & & & & & \\
\hline \multirow[t]{2}{*}{ seprate } & 0.0229 & 0.4256 & -0.2811 & 1.0000 & & & & & & & & & & & & & & \\
\hline & 0.0119 & $<.0001$ & $<.0001$ & & & & & & & & & & & & & & & \\
\hline \multirow[t]{2}{*}{ mobility } & 0.2387 & 0.3236 & 0.5344 & 0.6608 & 1.0000 & & & & & & & & & & & & & \\
\hline & $<.0001$ & $<.0001$ & $<.0001$ & $<.0001$ & & & & & & & & & & & & & & \\
\hline \multirow[t]{2}{*}{ netemply } & 0.1489 & -0.3197 & 0.7729 & -0.8262 & -0.1231 & 1.0000 & & & & & & & & & & & & \\
\hline & $<.0001$ & $<.0001$ & $<.0001$ & $<.0001$ & $<.0001$ & & & & & & & & & & & & & \\
\hline \multirow[t]{2}{*}{ employee } & 0.9039 & 0.7943 & 0.0302 & 0.1374 & 0.1447 & -0.0730 & 1.0000 & & & & & & & & & & & \\
\hline & $<.0001$ & $<.0001$ & 0.0009 & $<.0001$ & $<.0001$ & $<.0001$ & & & & & & & & & & & & \\
\hline \multirow[t]{2}{*}{ lowman } & 0.9008 & 0.7658 & 0.0460 & 0.1016 & 0.1255 & -0.0401 & 0.9916 & 1.0000 & & & & & & & & & & \\
\hline & $<.0001$ & $<.0001$ & $<.0001$ & $<.0001$ & $<.0001$ & $<.0001$ & $<.0001$ & & & & & & & & & & & \\
\hline \multirow[t]{2}{*}{ midman } & 0.8643 & 0.8055 & 0.0046 & 0.1813 & 0.16340 & -0.1171 & 0.9693 & 0.9347 & 1.0000 & & & & & & & & & \\
\hline & $<.0001$ & $<.0001$ & 0.6060 & $<.0001$ & $<.0001$ & $<.0001$ & $<.0001$ & $<.0001$ & & & & & & & & & & \\
\hline \multirow[t]{2}{*}{ topman } & 0.6244 & 0.6352 & -0.0469 & 0.2594 & 0.1917 & -0.1990 & 0.6918 & 0.6184 & 0.7098 & 1.0000 & & & & & & & & \\
\hline & $<.0001$ & $<.0001$ & $<.0001$ & $<.0001$ & $<.0001$ & $<.0001$ & $<.0001$ & $<.0001$ & $<.0001$ & & & & & & & & & \\
\hline male & 0.8233 & 0.6972 & 0.0448 & 0.1375 & 0.1562 & -0.0645 & 0.8843 & 0.9041 & 0.7690 & 0.6665 & 1.0000 & & & & & & & \\
\hline
\end{tabular}


Prob $>|r|$ under H0: Rho $=0$

\begin{tabular}{|c|c|c|c|c|c|c|c|c|c|c|c|c|c|c|c|c|c|c|}
\hline \multicolumn{19}{|c|}{ Prob $>|r|$ under H0: Rho $=0$} \\
\hline & hiring & separate & hirerate & seprate & mobility & netemply & employee & lowman & midman & topman & male & female & age1824 & age2534 & age3544 & age4554 & age5564 & trend \\
\hline & $<.0001$ & $<.0001$ & $<.0001$ & $<.0001$ & $<.0001$ & $<.0001$ & $<.0001$ & $<.0001$ & $<.0001$ & $<.0001$ & & & & & & & & \\
\hline \multirow[t]{2}{*}{ female } & 0.5617 & 0.5357 & -0.0091 & 0.0656 & 0.0506 & -0.0487 & 0.6639 & 0.6146 & 0.7848 & 0.3716 & 0.2380 & 1.0000 & & & & & & \\
\hline & $<.0001$ & $<.0001$ & 0.3130 & $<.0001$ & $<.0001$ & $<.0001$ & $<.0001$ & $<.0001$ & $<.0001$ & $<.0001$ & $<.0001$ & & & & & & & \\
\hline \multirow[t]{2}{*}{ age1824 } & 0.8900 & 0.8082 & 0.0299 & 0.1547 & 0.1597 & -0.0847 & 0.9848 & 0.9727 & 0.9619 & 0.6921 & 0.8727 & 0.6510 & 1.0000 & & & & & \\
\hline & $<.0001$ & $<.0001$ & 0.0010 & $<.0001$ & $<.0001$ & $<.0001$ & $<.0001$ & $<.0001$ & $<.0001$ & $<.0001$ & $<.0001$ & $<.0001$ & & & & & & \\
\hline \multirow[t]{2}{*}{ age2534 } & 0.8793 & 0.7622 & 0.0536 & 0.0970 & 0.1274 & -0.0326 & 0.9606 & 0.9495 & 0.9519 & 0.6179 & 0.7714 & 0.7627 & 0.9409 & 1.0000 & & & & \\
\hline & $<.0001$ & $<.0001$ & $<.0001$ & $<.0001$ & $<.0001$ & 0.0003 & $<.0001$ & $<.0001$ & $<.0001$ & $<.0001$ & $<.0001$ & $<.0001$ & $<.0001$ & & & & & \\
\hline \multirow[t]{2}{*}{ age3544 } & 0.8983 & 0.8069 & 0.0236 & 0.1535 & 0.1537 & -0.0876 & 0.9975 & 0.9862 & 0.9733 & 0.6954 & 0.8815 & 0.6633 & 0.9858 & 0.9526 & 1.00000 & & & \\
\hline & $<.0001$ & $<.0001$ & 0.0094 & $<.0001$ & $<.0001$ & $<.0001$ & $<.0001$ & $<.0001$ & $<.0001$ & $<.0001$ & $<.0001$ & $<.0001$ & $<.0001$ & $<.0001$ & & & & \\
\hline \multirow[t]{2}{*}{ age4554 } & 0.8880 & 0.7791 & 0.0207 & 0.1426 & 0.1418 & -0.0821 & 0.9931 & 0.9851 & 0.9629 & 0.6822 & 0.8799 & 0.6573 & 0.9708 & 0.9380 & 0.9915 & 1.0000 & & \\
\hline & $<.0001$ & $<.0001$ & 0.0227 & $<.0001$ & $<.0001$ & $<.0001$ & $<.0001$ & $<.0001$ & $<.0001$ & $<.0001$ & $<.0001$ & $<.0001$ & $<.0001$ & $<.0001$ & $<.0001$ & & & \\
\hline \multirow[t]{2}{*}{ age5564 } & 0.8179 & 0.6792 & 0.0233 & 0.1107 & 0.1158 & -0.0595 & 0.8904 & 0.9011 & 0.7930 & 0.6940 & 0.9355 & 0.3541 & 0.8622 & 0.7762 & 0.8788 & 0.8835 & 1.0000 & \\
\hline & $<.0001$ & $<.0001$ & 0.0104 & $<.0001$ & $<.0001$ & $<.0001$ & $<.0001$ & $<.0001$ & $<.0001$ & $<.0001$ & $<.0001$ & $<.0001$ & $<.0001$ & $<.0001$ & $<.0001$ & $<.0001$ & & \\
\hline \multirow[t]{2}{*}{ trend } & -0.0904 & 0.0738 & -0.2650 & 0.1413 & -0.0827 & -0.2490 & 0.0076 & 0.0104 & 0.0005 & 0.0026 & -0.0002 & 0.0164 & 0.0028 & 0.0246 & -0.0006 & -0.0041 & 0.0383 & 1.0000 \\
\hline & $<.0001$ & $<.0001$ & $<.0001$ & $<.0001$ & $<.0001$ & $<.0001$ & 0.4005 & 0.2493 & 0.9510 & 0.7739 & 0.9756 & 0.0701 & 0.7546 & 0.0067 & 0.9468 & 0.6473 & $<.0001$ & \\
\hline
\end{tabular}


Table 3.A Hiring and Separation levels Pooled parameter estimates

\begin{tabular}{|l|r|r|r|r|r|r|}
\hline & \multicolumn{3}{|c|}{ Hiring level } & \multicolumn{3}{|c|}{ Separation level } \\
\hline Variable & $\begin{array}{r}\text { Parameter } \\
\text { Estimate }\end{array}$ & $\begin{array}{r}\text { Robust } \\
\text { Std Err }\end{array}$ & Pr $>|t|$ & $\begin{array}{r}\text { Parameter } \\
\text { Estimate }\end{array}$ & $\begin{array}{r}\text { Robust } \\
\text { Std Err }\end{array}$ & Pr $|\mathrm{t}|$ \\
\hline Intercept & 1.85453 & 0.14136 & $<.0001$ & -5.05177 & 1.07009 & $<.0001$ \\
\hline employee & 0.03689 & 0.01800 & 0.0404 & -0.18653 & 0.11774 & 0.1131 \\
\hline midman & 0.06075 & 0.01709 & 0.0004 & 0.23032 & 0.08720 & 0.0083 \\
\hline topman & -0.02647 & 0.01006 & 0.0085 & 0.15660 & 0.05977 & 0.0088 \\
\hline male & 0.01538 & 0.00253 & $<.0001$ & 0.02477 & 0.01074 & 0.0211 \\
\hline age2534 & 0.04652 & 0.01886 & 0.0137 & 0.13447 & 0.11948 & 0.2604 \\
\hline age3544 & -0.08418 & 0.03648 & 0.0211 & 0.33688 & 0.23973 & 0.1600 \\
\hline age4554 & -0.04259 & 0.02185 & 0.0513 & 0.00541 & 0.09892 & 0.9564 \\
\hline age5564 & -0.00051 & 0.01791 & 0.9773 & 0.11995 & 0.11069 & 0.2786 \\
\hline d2008 & -1.24498 & 0.04780 & $<.0001$ & 0.94081 & 0.10828 & $<.0001$ \\
\hline d2009 & -2.80717 & 0.04452 & $<.0001$ & 2.18357 & 0.05928 & $<.0001$ \\
\hline d2010 & -1.02244 & 0.04763 & $<.0001$ & 0.80842 & 0.08740 & $<.0001$ \\
\hline d2011 & -1.97511 & 0.07731 & $<.0001$ & 2.81988 & 0.37482 & $<.0001$ \\
\hline d2012 & -1.27828 & 0.04840 & $<.0001$ & 0.94125 & 0.10823 & $<.0001$ \\
\hline quart2 & -0.05162 & 0.03501 & 0.1404 & 0.12368 & 0.04948 & 0.0124 \\
\hline quart3 & -0.31303 & 0.03350 & $<.0001$ & 0.45159 & 0.06597 & $<.0001$ \\
\hline quart4 & -1.38874 & 0.04007 & $<.0001$ & 1.19839 & 0.05251 & $<.0001$ \\
\hline service & 0.30787 & 0.14171 & 0.0298 & 3.35966 & 1.11665 & 0.0026 \\
\hline trade & -0.01626 & 0.15892 & 0.9185 & 3.38169 & 1.20936 & 0.0052 \\
\hline construct & -0.05312 & 0.17327 & 0.7592 & 3.46248 & 1.20010 & 0.0039 \\
\hline manufact & -0.56138 & 0.16138 & 0.0005 & 2.66097 & 0.96582 & 0.0059 \\
\hline arab spring & -0.96807 & 0.08507 & $<.0001$ & -0.21998 & 0.41864 & 0.5993 \\
\hline & & & & & & \\
\hline R2 adj & 0.8964 & & & 0.7482 & & \\
\hline RMSE & 1.3992 & & & 2.7227 & & \\
\hline F-value & 4974.4500 & & & 1708.5600 & & \\
\hline
\end{tabular}


Table 3.B Hiring and Separation rates Pooled parameter estimates

\begin{tabular}{|l|r|r|r|r|r|r|}
\hline & \multicolumn{3}{|c|}{ Hiring rate } & \multicolumn{2}{|c|}{ Separation rate } \\
\hline Variable & $\begin{array}{r}\text { Parameter } \\
\text { Estimate }\end{array}$ & $\begin{array}{r}\text { Robust } \\
\text { Std Err }\end{array}$ & $\operatorname{Pr}>|t|$ & $\begin{array}{r}\text { Parameter } \\
\text { Estimate }\end{array}$ & $\begin{array}{r}\text { Robust } \\
\text { Std Err }\end{array}$ & Pr $|\mathrm{t}|$ \\
\hline Intercept & 0.09886 & 0.01969 & $<.0001$ & -0.10813 & 0.03216 & 0.0008 \\
\hline employee & 0.00001 & 0.000001 & $<.0001$ & 0.000005 & 0.000002 & 0.0065 \\
\hline midshare & -0.09477 & 0.03117 & 0.0024 & 0.07820 & 0.05604 & 0.1629 \\
\hline topshare & 0.00096 & 0.00632 & 0.8787 & -0.01034 & 0.00934 & 0.2685 \\
\hline maleshare & 0.04005 & 0.00802 & $<.0001$ & 0.05248 & 0.01720 & 0.0023 \\
\hline age2share & 0.03375 & 0.01931 & 0.0806 & 0.04518 & 0.03121 & 0.1477 \\
\hline age3share & -0.07239 & 0.03365 & 0.0315 & 0.23340 & 0.06324 & 0.0002 \\
\hline age4share & -0.04327 & 0.02149 & 0.0441 & -0.02333 & 0.04170 & 0.5758 \\
\hline age5share & -0.05403 & 0.01806 & 0.0028 & 0.06590 & 0.02995 & 0.0278 \\
\hline d2008 & -0.01766 & 0.00054 & $<.0001$ & 0.00986 & 0.00054 & $<.0001$ \\
\hline d2009 & -0.03396 & 0.00045 & $<.0001$ & 0.01833 & 0.00065 & $<.0001$ \\
\hline d2010 & -0.01442 & 0.00055 & $<.0001$ & 0.00949 & 0.00059 & $<.0001$ \\
\hline d2011 & -0.02736 & 0.00069 & $<.0001$ & 0.01684 & 0.00163 & $<.0001$ \\
\hline d2012 & -0.01787 & 0.00054 & $<.0001$ & 0.00986 & 0.00055 & $<.0001$ \\
\hline quart2 & -0.00059 & 0.00042 & 0.1626 & 0.00029 & 0.00039 & 0.4652 \\
\hline quart3 & -0.00377 & 0.00041 & $<.0001$ & 0.00486 & 0.00047 & $<.0001$ \\
\hline quart4 & -0.01331 & 0.00043 & $<.0001$ & 0.01396 & 0.00051 & $<.0001$ \\
\hline service & -0.01525 & 0.00795 & 0.0549 & -0.00625 & 0.01232 & 0.6121 \\
\hline trade & -0.01361 & 0.00645 & 0.0347 & 0.00401 & 0.00970 & 0.6790 \\
\hline construct & -0.03051 & 0.00958 & 0.0014 & -0.01798 & 0.01655 & 0.2775 \\
\hline manufact & -0.00948 & 0.00457 & 0.0381 & 0.00329 & 0.00671 & 0.6241 \\
\hline arab spring & -0.00760 & 0.00071 & $<.0001$ & 0.00664 & 0.00183 & 0.0003 \\
\hline & & & & & & \\
\hline R2 adj & 0.4672 & & & 0.3396 & & \\
\hline RMSE & 2.4395 & & & 0.0191 & & \\
\hline F-value & 505.0600 & & & 296.6100 & & \\
\hline
\end{tabular}


Table 3.C Mobility and Net-employment parameter estimates

\begin{tabular}{|l|r|r|r|r|r|r|}
\hline & \multicolumn{3}{|c|}{ Mobility } & \multicolumn{2}{|c|}{ Net-employment } \\
\hline Variable & $\begin{array}{r}\text { Parameter } \\
\text { Estimate }\end{array}$ & $\begin{array}{r}\text { Robust } \\
\text { Std Err }\end{array}$ & Pr $>|\mathrm{t}|$ & $\begin{array}{r}\text { Parameter } \\
\text { Estimate }\end{array}$ & $\begin{array}{r}\text { Robust } \\
\text { Std Err }\end{array}$ & Pr $>|\mathrm{t}|$ \\
\hline Intercept & -0.00927 & 0.03688 & 0.8016 & 0.20699 & 0.03852 & $<.0001$ \\
\hline employee & 0.000018 & 0.000002 & $<.0001$ & 0.000008 & 0.000002 & 0.0002 \\
\hline midshare & 0.01657 & 0.05979 & 0.7817 & -0.17297 & 0.06817 & 0.0112 \\
\hline topshare & -0.00937 & 0.01101 & 0.3947 & 0.01130 & 0.01154 & 0.3276 \\
\hline maleshare & 0.09253 & 0.02001 & $<.0001$ & -0.01242 & 0.01788 & 0.4873 \\
\hline age2share & 0.07892 & 0.03599 & 0.0284 & -0.01143 & 0.03739 & 0.7598 \\
\hline age3share & 0.16101 & 0.06993 & 0.0213 & -0.30580 & 0.07331 & $<.0001$ \\
\hline age4share & -0.06660 & 0.04803 & 0.1656 & -0.01994 & 0.04577 & 0.6631 \\
\hline age5share & -0.01188 & 0.03380 & 0.7253 & -0.11993 & 0.03610 & 0.0009 \\
\hline d2008 & -0.00779 & 0.00076 & $<.0001$ & -0.02752 & 0.00075 & $<.0001$ \\
\hline d2009 & -0.01564 & 0.00078 & $<.0001$ & -0.05229 & 0.00079 & $<.0001$ \\
\hline d2010 & -0.00492 & 0.00075 & $<.0001$ & -0.02391 & 0.00087 & $<.0001$ \\
\hline d2011 & -0.01051 & 0.00181 & $<.0001$ & -0.04420 & 0.00174 & $<.0001$ \\
\hline d2012 & -0.00801 & 0.00077 & $<.0001$ & -0.02774 & 0.00077 & $<.0001$ \\
\hline quart2 & -0.00030 & 0.00059 & 0.6121 & -0.00088 & 0.00056 & 0.1201 \\
\hline quart3 & 0.00108 & 0.00064 & 0.0949 & -0.00863 & 0.00061 & $<.0001$ \\
\hline quart4 & 0.00065 & 0.00066 & 0.3301 & -0.02727 & 0.00067 & $<.0001$ \\
\hline service & -0.02150 & 0.01373 & 0.1173 & -0.00900 & 0.01554 & 0.5624 \\
\hline trade & -0.00960 & 0.01134 & 0.3972 & -0.01763 & 0.01194 & 0.1399 \\
\hline construct & -0.04849 & 0.01818 & 0.0077 & -0.01253 & 0.02003 & 0.5314 \\
\hline manufact & -0.00620 & 0.00792 & 0.4343 & -0.01277 & 0.00831 & 0.1243 \\
\hline arab spring & -0.00096 & 0.00201 & 0.6340 & -0.01423 & 0.00192 & $<.0001$ \\
\hline & & & & & & \\
\hline R2 adj & 0.1274 & & & 0.5471 & & \\
\hline RMSE & 0.0248 & & & 0.0238 & & \\
\hline F-value & 84.9600 & & & 695.4300 & & \\
\hline
\end{tabular}


Table 3.D Mobility and Net-employment parameter estimates by firm size

\begin{tabular}{|c|c|c|c|c|c|c|c|c|c|c|c|c|}
\hline & \multicolumn{3}{|c|}{ Small Size } & \multicolumn{3}{|c|}{ Small Size } & \multicolumn{3}{|c|}{ Large Size } & \multicolumn{3}{|c|}{ Large Size } \\
\hline & \multicolumn{3}{|c|}{ Mobility } & \multicolumn{3}{|c|}{ Net-employment } & \multicolumn{3}{|c|}{ Mobility } & \multicolumn{3}{|c|}{ Net-employment } \\
\hline Variable & $\begin{array}{r}\text { Parameter } \\
\text { Estimate }\end{array}$ & $\begin{array}{l}\text { Robust } \\
\text { Std Err }\end{array}$ & $\operatorname{Pr}>|t|$ & $\begin{array}{r}\text { Parameter } \\
\text { Estimate }\end{array}$ & $\begin{array}{l}\text { Robust } \\
\text { Std Err }\end{array}$ & $\operatorname{Pr}>|t|$ & $\begin{array}{r}\text { Parameter } \\
\text { Estimate }\end{array}$ & $\begin{array}{l}\text { Robust } \\
\text { Std Err }\end{array}$ & $\operatorname{Pr}>|t|$ & $\begin{array}{r}\text { Parameter } \\
\text { Estimate }\end{array}$ & $\begin{array}{l}\text { Robust } \\
\text { Std Err }\end{array}$ & $\operatorname{Pr}>|t|$ \\
\hline Intercept & -0.04386 & 0.03713 & 0.2376 & 0.20581 & 0.04032 & $<.0001$ & -0.10048 & 0.07998 & 0.2091 & 0.33057 & 0.06937 & $<.0001$ \\
\hline employee & -0.00023 & 0.00006 & 0.0001 & 0.00027 & 0.00006 & $<.0001$ & 0.00002 & 0.000002 & $<.0001$ & $-1.129 \mathrm{E}-7$ & 0.000002 & 0.9472 \\
\hline midshare & -0.07978 & 0.05868 & 0.1740 & -0.15887 & 0.07596 & 0.0365 & 0.30453 & 0.10301 & 0.0031 & -0.24078 & 0.10069 & 0.0168 \\
\hline topshare & -0.01669 & 0.01212 & 0.1684 & 0.03565 & 0.01305 & 0.0063 & 0.07283 & 0.04816 & 0.1306 & -0.08131 & 0.05077 & 0.1093 \\
\hline maleshare & 0.18973 & 0.03016 & $<.0001$ & -0.03609 & 0.03071 & 0.2400 & 0.01093 & 0.01864 & 0.5579 & -0.00256 & 0.01763 & 0.8844 \\
\hline age2share & 0.11441 & 0.03701 & 0.0020 & 0.00207 & 0.04066 & 0.9594 & 0.09497 & 0.06838 & 0.1649 & -0.13136 & 0.06318 & 0.0377 \\
\hline age3share & 0.09923 & 0.06440 & 0.1234 & -0.27050 & 0.07195 & 0.0002 & 0.06179 & 0.13341 & 0.6433 & -0.36833 & 0.13950 & 0.0083 \\
\hline age4share & -0.02010 & 0.05196 & 0.6989 & -0.06365 & 0.05266 & 0.2268 & -0.09588 & 0.08232 & 0.2442 & -0.09446 & 0.08749 & 0.2803 \\
\hline age5share & -0.05704 & 0.03553 & 0.1085 & -0.12077 & 0.04066 & 0.0030 & -0.00980 & 0.06131 & 0.8731 & -0.16975 & 0.05563 & 0.0023 \\
\hline d2008 & -0.00819 & 0.00131 & $<.0001$ & -0.03827 & 0.00128 & $<.0001$ & -0.00338 & 0.00067 & $<.0001$ & -0.01699 & 0.00062 & $<.0001$ \\
\hline d2009 & -0.02365 & 0.00129 & $<.0001$ & -0.06317 & 0.00133 & $<.0001$ & -0.00547 & 0.00058 & $<.0001$ & -0.04023 & 0.00051 & $<.0001$ \\
\hline d2010 & -0.00455 & 0.00134 & 0.0007 & -0.03153 & 0.00159 & $<.0001$ & -0.00224 & 0.00063 & 0.0004 & -0.01567 & 0.00064 & $<.0001$ \\
\hline d2011 & -0.02586 & 0.00277 & $<.0001$ & -0.04924 & 0.00270 & $<.0001$ & 0.00402 & 0.00184 & 0.0286 & -0.03660 & 0.00180 & $<.0001$ \\
\hline d2012 & -0.00848 & 0.00134 & $<.0001$ & -0.03849 & 0.00131 & $<.0001$ & -0.00357 & 0.00068 & $<.0001$ & -0.01719 & 0.00062 & $<.0001$ \\
\hline quart2 & -0.00129 & 0.00105 & 0.2201 & -0.00115 & 0.00101 & 0.2544 & 0.00106 & 0.00046 & 0.0212 & -0.00063 & 0.00043 & 0.1426 \\
\hline quart3 & 0.00316 & 0.00112 & 0.0048 & -0.01207 & 0.00109 & $<.0001$ & -0.00032 & 0.00052 & 0.5417 & -0.00520 & 0.00045 & $<.0001$ \\
\hline quart4 & 0.00478 & 0.00115 & $<.0001$ & -0.03446 & 0.00121 & $<.0001$ & -0.00297 & 0.00048 & $<.0001$ & -0.01992 & 0.00047 & $<.0001$ \\
\hline service & -0.03736 & 0.01362 & 0.0061 & 0.00039 & 0.01740 & 0.9818 & 0.08184 & 0.03038 & 0.0071 & -0.06046 & 0.02993 & 0.0434 \\
\hline trade & 0.00214 & 0.01115 & 0.8478 & -0.01401 & 0.01136 & 0.2176 & 0.05650 & 0.02905 & 0.0518 & -0.06165 & 0.02990 & 0.0392 \\
\hline construct & -0.09209 & 0.02048 & $<.0001$ & -0.00195 & 0.02562 & 0.9394 & 0.07889 & 0.03322 & 0.0176 & -0.06693 & 0.03174 & 0.0350 \\
\hline manufact & -0.01117 & 0.00813 & 0.1697 & -0.00672 & 0.00797 & 0.3991 & 0.05312 & 0.02464 & 0.0311 & -0.05480 & 0.02555 & 0.0320 \\
\hline arab spring & 0.00962 & 0.00317 & 0.0024 & -0.02239 & 0.00311 & $<.0001$ & -0.00936 & 0.00199 & $<.0001$ & -0.00757 & 0.00199 & 0.0001 \\
\hline R2 adj & 0.1511 & & & 0.5445 & & & 0.3463 & & & 0.6696 & & \\
\hline RMSE & 0.0302 & & & 0.0297 & & & 0.0146 & & & 0.0138 & & \\
\hline F-value & 52.8700 & & & 349.3900 & & & 151.0900 & & & 575.0500 & & \\
\hline
\end{tabular}


Table 3.E Mobility and Net-employment parameter estimates by Formal/Informal sector

\begin{tabular}{|c|c|c|c|c|c|c|c|c|c|c|c|c|}
\hline & \multicolumn{3}{|c|}{ Formal sector } & \multicolumn{3}{|c|}{ Formal sector } & \multicolumn{3}{|c|}{ Informal sector } & \multicolumn{3}{|c|}{ Informal sector } \\
\hline & \multicolumn{3}{|c|}{ Mobility } & \multicolumn{3}{|c|}{ Net-employment } & \multicolumn{3}{|c|}{ Mobility } & \multicolumn{3}{|c|}{ Net-employment } \\
\hline Variable & $\begin{array}{r}\text { Parameter } \\
\text { Estimate }\end{array}$ & $\begin{array}{l}\text { Robust } \\
\text { Std Err }\end{array}$ & $\operatorname{Pr}>|t|$ & $\begin{array}{r}\text { Parameter } \\
\text { Estimate }\end{array}$ & $\begin{array}{l}\text { Robust } \\
\text { Std Err }\end{array}$ & $\operatorname{Pr}>|t|$ & $\begin{array}{r}\text { Parameter } \\
\text { Estimate }\end{array}$ & $\begin{array}{l}\text { Robust } \\
\text { Std Err }\end{array}$ & $\operatorname{Pr}>|t|$ & $\begin{array}{r}\text { Parameter } \\
\text { Estimate }\end{array}$ & $\begin{array}{l}\text { Robust } \\
\text { Std Err }\end{array}$ & $\operatorname{Pr}>|t|$ \\
\hline Intercept & -0.05526 & 0.04728 & 0.2426 & 0.18230 & 0.05767 & 0.0016 & -0.09168 & 0.03860 & 0.0176 & 0.28536 & 0.03785 & $<.0001$ \\
\hline employee & 0.000015 & 0.000004 & 0.0002 & 0.00001 & 0.000004 & 0.0032 & 0.00002 & 0.000003 & $<.0001$ & 0.000007 & 0.000004 & 0.0623 \\
\hline midshare & -0.13337 & 0.04033 & 0.0009 & -0.07496 & 0.05926 & 0.2059 & 0.30852 & 0.06833 & $<.0001$ & -0.27402 & 0.06660 & $<.0001$ \\
\hline topshare & -0.02448 & 0.00732 & 0.0008 & 0.04250 & 0.00689 & $<.0001$ & 0.02346 & 0.01467 & 0.1099 & 0.00136 & 0.01412 & 0.9231 \\
\hline maleshare & 0.24677 & 0.03424 & $<.0001$ & -0.05606 & 0.04563 & 0.2193 & -0.01634 & 0.00483 & 0.0007 & -0.01213 & 0.00464 & 0.0090 \\
\hline age2share & 0.10121 & 0.04592 & 0.0276 & 0.01411 & 0.05504 & 0.7976 & 0.16920 & 0.04234 & $<.0001$ & -0.22097 & 0.04205 & $<.0001$ \\
\hline age3share & 0.13799 & 0.07152 & 0.0537 & -0.27723 & 0.08877 & 0.0018 & 0.15548 & 0.07193 & 0.0307 & -0.30442 & 0.07191 & $<.0001$ \\
\hline age4share & -0.05186 & 0.05344 & 0.3319 & -0.04238 & 0.06230 & 0.4964 & 0.08885 & 0.05971 & 0.1368 & -0.12697 & 0.05725 & 0.0266 \\
\hline age5share & 0.11188 & 0.04738 & 0.0182 & -0.15302 & 0.05969 & 0.0104 & 0.01283 & 0.03490 & 0.7133 & -0.17136 & 0.03522 & $<.0001$ \\
\hline d2008 & -0.01025 & 0.00103 & $<.0001$ & -0.03421 & 0.00089 & $<.0001$ & -0.00075 & 0.00107 & 0.4813 & -0.01770 & 0.00108 & $<.0001$ \\
\hline d2009 & -0.01091 & 0.00096 & $<.0001$ & -0.06057 & 0.00095 & $<.0001$ & -0.01888 & 0.00105 & $<.0001$ & -0.04454 & 0.00099 & $<.0001$ \\
\hline $\mathrm{d} 2010$ & -0.00678 & 0.00097 & $<.0001$ & -0.02741 & 0.00113 & $<.0001$ & -0.00113 & 0.00122 & 0.3572 & -0.01791 & 0.00121 & $<.0001$ \\
\hline d2011 & -0.01003 & 0.00223 & $<.0001$ & -0.05241 & 0.00231 & $<.0001$ & -0.01526 & 0.00240 & $<.0001$ & -0.03502 & 0.00232 & $<.0001$ \\
\hline $\mathrm{d} 2012$ & -0.01044 & 0.00104 & $<.0001$ & -0.03445 & 0.00092 & $<.0001$ & -0.00098 & 0.00108 & 0.3605 & -0.01787 & 0.00109 & $<.0001$ \\
\hline quart2 & -0.00053 & 0.00086 & 0.5372 & -0.00028 & 0.00085 & 0.7414 & 0.00200 & 0.00067 & 0.0029 & -0.00327 & 0.00064 & $<.0001$ \\
\hline quart3 & 0.00297 & 0.00089 & 0.0008 & -0.01357 & 0.00085 & $<.0001$ & 0.00099 & 0.00083 & 0.2289 & -0.00345 & 0.00081 & $<.0001$ \\
\hline quart4 & -0.00091 & 0.00088 & 0.3004 & -0.02303 & 0.00090 & $<.0001$ & 0.00492 & 0.00084 & $<.0001$ & -0.03548 & 0.00089 & $<.0001$ \\
\hline arab spring & 0.00067 & 0.00243 & 0.7818 & -0.01277 & 0.00254 & $<.0001$ & 0.00287 & 0.00279 & 0.3039 & -0.01789 & 0.00276 & $<.0001$ \\
\hline R2 adj & 0.1742 & & & 0.5595 & & & 0.3411 & & & 0.6081 & & \\
\hline RMSE & 0.0262 & & & 0.0252 & & & 0.0191 & & & 0.0191 & & \\
\hline F-value & 74.3300 & & & 540.7600 & & & 148.6000 & & & 443.3900 & & \\
\hline
\end{tabular}

